\title{
THE INFLUENCE OF SHIFT WORK ON THE OCCURRENCE OF HYPERTENSION, ISCHEMIC HEART DISEASE AND DYSLIPIDEMIA FROM THE PERSPECTIVE OF MINE SHIFT WORKERS
}

\section{WPEYW PRACY ZMIANOWEJ NA WYSTĘPOWANIE NADCIŚNIENIA TĘTNICZEGO, CHOROBY NIEDOKRWIENNEJ SERCA I ZABURZEŃ LIPIDOGRAMU W OPINII PRACOWNIKÓW ZMIANOWYCH KOPALNI}

\author{
Joanna Strzemecka ${ }^{1(\mathrm{~A}, \mathrm{~B}, \mathrm{C}, \mathrm{D}, \mathrm{E}, \mathrm{F})}$, Jerzy Skrodziuk ${ }^{2(\mathrm{~B}, \mathrm{E}, \mathrm{F})}$
}

${ }^{1}$ Pope John Paul II State School of Higher Education in Biała Podlaska, Poland

${ }^{2}$ Faculty of Physical Education and Sport in Biała Podlaska, Józef Piłsudski University

of Physical Education in Warsaw, Poland

Authors' contribution

Wkład autorów:

A. Study design/planning

zaplanowanie badań

B. Data collection/entry

zebranie danych

C. Data analysis/statistics

dane - analiza i statystyki

D. Data interpretation

interpretacja danych

E. Preparation of manuscript

przygotowanie artykułu

F. Literature analysis/search

wyszukiwanie i analiza literatury

G. Funds collection

zebranie funduszy
Tables: 8

Figures: 0

References: 15

Submitted: 2019 Apr 4

Accepted: 2019 Apr 16
Summary

Background. Shift work may affect the occurrence and severity of hypertension, ischemic heart disease and dyslipidemia. The aim of the study was to assess the prevalence of ischemic heart disease, hypertension and dyslipidemia in shift workers. Material and methods. The study was carried out in the Bogdanka mine in Łęczna, Poland. The questionnaire, which was designed by the author of this work, was conducted among 700 shift workers who worked underground in the mine. Statistical analysis was performed using STATISTICA v. 7.1 (StatSoft, Poland) software. Results. Participants who believed that shift work may lead to deterioration of their health also believed that it may affect the occurrence of ischemic heart disease and hypertension. Almost one in four respondents had blood pressure values of $>139 / 89 \mathrm{mmHg}$. Almost one in ten respondents was receiving treatment for hypertension. A small number of respondents reported abnormal total cholesterol, HDL cholesterol and triglyceride levels. Conclusions. In the opinion of respondents, shift work can exacerbate hypertension and ischemic heart disease. Abnormal values of total cholesterol and its LDL and HDL fractions increased with age and length of work, while abnormal triglyceride values were reported most frequently by supervisors. It seems necessary to introduce training for shift workers, aimed at presenting them with the principles of prevention of cardiovascular diseases; for example, how to deal with stress, change eating habits, stop smoking and reduce coffee intake, and how to encourage physical activity and good sleep hygiene.

Keywords: hypertension, ischemic heart disease, lipids, shift-work

\section{Streszczenie}

Wprowadzenie. Praca zmianowa ma wpływ na występowanie i zaostrzenie nadciśnienia tętniczego, choroby niedokrwiennej serca, czy nieprawidłowych wartości lipidogramu. Celem pracy była ocena występowania u pracowników zmianowych choroby niedokrwiennej serca, nadciśnienia tętniczego i zaburzeń lipidogramu. Materiał i metody. Badanie przeprowadzono w kopalni "Bogdanka” w Łęcznej. Kwestionariusz własnej konstrukcji rozdano wśród 700 podziemnych pracowników zmianowych. Analizę statystyczną otrzymanych wyników przeprowadzono w oparciu o program statystyczny STATISTICA v. 7.1 (StatSoft, Polska). Wyniki. Osoby potwierdzające, że praca zmianowa może prowadzić do pogorszenia stanu zdrowia, uważały, że może ona wpływać na występowanie zaostrzeń choroby niedokrwiennej serca i nadciśnienia tętniczego. Prawie co czwarty ankietowany miał wartości ciśnienia $>$ 139/89 mmHg. Prawie co dziesiąty ankietowany leczył się na nadciśnienie tętnicze. Nieliczny odsetek ankietowanych zaobserwował u siebie nieprawidłowe wartości cholesterolu HDL, TGL oraz cholesterolu całkowitego. Wnioski. W ocenie respondentów praca zmianowa może być przyczyną zaostrzenia nadciśnienia i choroby niedokrwiennej serca. Występowanie nieprawidłowych wartości całkowitego cholesterolu i jego frakcji LDL i HDL wzrastało wraz z wiekiem i długościa pracy, natomiast nieprawidłowe wartości TGL najczę́́ciej zgłaszały osoby sprawujące nadzór. Wydaje się koniecznym wprowadzenie szkoleń dla pracowników zmianowych, mających na celu przedstawienie im zasad profilaktyki w chorobach sercowo naczyniowych, przykładowo: jak radzić sobie ze stresem, jak zmienić nawyki żywieniowe, zaprzestanie palenia papierosów i picia kawy, dobrze prowadzona aktywność fizyczna, dobra higiena snu.

Słowa kluczowe: nadciśnienie tętnicze, choroba niedokrwienna serca, lipidogram, praca zmianowa

Strzemecka J, Skrodziuk J. The influence of shift work on the occurrence of hypertension, ischemic heart disease and dyslipidemia from the perspective of mine shift workers. Health Prob Civil. 2019; 13(3): 187-192. https://doi.org/10.5114/hpc.2019.84665

Address for correspondence / Adres korespondencyjny: Joanna Strzemecka, Pope John Paul II State School of Higher Education, Sidorska 95/97, 21-500 Biała Address for correspondence / Adres korespondencyjny: Joanna Strzemeck

ORCID: Joanna Strzemecka https://orcid.org/0000-0002-1478-0162, Jerzy Skrodziuk https://orcid.org/0000-0001-6863-4753

Copyright: (C) Pope John Paul II State School of Higher Education in Biała Podlaska, Joanna Strzemecka, Jerzy Skrodziuk. This is an Open Access journal, all articles are distributed under the terms of the Creative Commons Attribution-NonCommercial-ShareAlike 4.0 International (CC BY-NC-SA 4.0) License (http://creativecommons.org/licenses/by-nc-sa/4.0/), allowing third parties to copy and redistribute the material in any medium or format and to remix, transform, and build upon the material, provided the original work is properly cited and states its license. 


\section{Introduction}

About $20 \%$ of workers in Europe are employed as shift workers, involving night work and extended hours $[1,2]$. Shift workers have been demonstrated to be at the increased risk of cardiovascular disease [3, 4]. Shift work is a risk factor for inflammation, elevated blood pressure, hypertension and cardiovascular disease, even after being controlled for traditional risk factors [5]. Shift workers, especially those working night shifts, must function in a setting that is unnatural. Sleep, wakefulness, digestion, adrenaline secretion, body temperature, blood pressure, pulse and many other body functions are regulated by circadian rhythm [6, 7]. In one study, shift work was found to be associated with early manifestations of cardiovascular disease [8]. The evidence suggests different interrelated pathways of how shift work leads to cardiovascular disease [9]. In addition, night shift work affecting cardiometabolic health increases blood pressure [10]. Working shifts may lead to behavioral changes, such as smoking, poor diet and reduced physical activity, which increases the risk of cardiovascular disease. Another theory is that shift work leads to desynchronization of the circadian rhythm and biological clock. A third theory suggests that disruption of the circadian rhythm due to shift work can cause imbalanced autonomic regulation of the cardiovascular system [9]. The aim of this study was to assess the occurrence of ischemic heart disease (IHD), hypertension and dyslipidemia in shift workers.

\section{Material and methods}

The studies were conducted in the Bogdanka mine in Łęczna, Poland. Respondents working underground shifts were randomly selected, independent of their position. 700 workers were interviewed. The questionnaire was designed by the author of this study. In order to verify this scientific tool, a pilot investigation was carried out (50 people). This approach created the final version of the questionnaire. The questionnaire included the following domains: age, education, workplace, length of shift work and the impact of shift work on the occurrence of IHD, hypertension and dyslipidemia. The results were subjected to statistical analysis. In order to identify distinctions and relationships between variables, $\chi^{2}$ test was used. For small numbers, Yates correction was applied. A 5\% inference error was used. Values with a probability of $\mathrm{p}<0.05$ were considered statistically significant. The statistical analysis was conducted with STATISTICA v. 7.1 software (StatSoft, Poland).

\section{Results}

Taking into account the self-assessment nature of the study, the relationship between age, education, position and number of years of work and selected cardiovascular diseases was analyzed. Exacerbation of IHD due to shift work was most frequently reported by people with primary education (8.3\%) (Table 1). Hypertension was most frequently reported by people aged 51 and over $(12.1 \%)$, compared to younger respondents ( $p<0.05)$. Respondents who believed that shift work can lead to deterioration of their health also believed that shiftwork may affect the occurrence of IHD (3.5\%) and hypertension $(9.7 \%)(\mathrm{p}<0.05)$ (Table 2). Almost a quarter of respondents (24.3\%) had a blood pressure $>139 / 89 \mathrm{mmHg}$. Among respondents with a blood pressure $>139 / 89$ $\mathrm{mmHg}, 31.9 \%$ were men aged $41-50$ and $30.3 \%$ had worked 21 years and more (Tables 3 and 4). Almost one in ten respondents was being treated for hypertension (8.7\%). The number of people treated for hypertension increased significantly with age and work experience (Table 4). Hypertension lasting 6 years and longer was reported by older people with longer work experience (Table 3). Abnormal lipid parameters among respondents were examined. Abnormal total cholesterol values were reported in people aged 51 and over (15.1\%) who had worked 21 years and longer (10.3\%). Abnormal LDL cholesterol values were reported most often in men aged 41-50 (2.6\%) who had worked for 11-20 years (3.0\%) ( $<<0$ 05). Abnormal HDL cholesterol values were reported significantly often $(\mathrm{p}<0.05)$ in people aged 51 and over $(6.1 \%)$ who had worked 21 years and longer $(4.6 \%)$ (Tables 5 and 6). Abnormal triglyceride values were most commonly reported in men working in supervisory positions (9.3\% p<0.05) (Table 7). Among respondents who said that shift work can lead to deterioration of their health, a small percent reported abnormal values of HDL cholesterol (3.9\%), triglycerides (3.9\%) which was statistically significant $\mathrm{p}<0.05$ and total cholesterol $(8.7 \%)$ which was close to the significant level $\mathrm{p} \leq 0.05$ (Table 8). 
Table 1. Shift work as the reason for respondents' self-reported exacerbation, ischemic heart disease and hypertension according to their education

\begin{tabular}{|c|c|c|c|c|c|c|c|c|}
\hline & & \multicolumn{5}{|c|}{ Education } & \multirow[b]{2}{*}{ Summary } & \multirow[b]{2}{*}{ Statistic } \\
\hline$*$ & & $\begin{array}{c}\text { Higher } \\
\text { education }\end{array}$ & Licentiate & \begin{tabular}{|l|} 
Secondary \\
education
\end{tabular} & \begin{tabular}{|l|}
$\begin{array}{l}\text { Vocational } \\
\text { education }\end{array}$ \\
\end{tabular} & $\begin{array}{c}\text { Primary } \\
\text { education }\end{array}$ & & \\
\hline \multirow{2}{*}{$\begin{array}{c}\text { Shift work as } \\
\text { the cause of } \\
\text { exacerbation } \\
\text { of: }\end{array}$} & IHD & $\begin{array}{c}0 \\
0.0 \%\end{array}$ & $\begin{array}{c}0 \\
0.0 \%\end{array}$ & $\begin{array}{c}9 \\
4.3 \%\end{array}$ & $\begin{array}{c}6 \\
1.6 \% \\
\end{array}$ & $\begin{array}{c}2 \\
8.3 \%\end{array}$ & $\begin{array}{c}17 \\
2.4 \%\end{array}$ & $\begin{array}{c}\chi^{2}=10.02 \\
p=0.04014\end{array}$ \\
\hline & Hypertension & $\begin{array}{c}4 \\
5.5 \%\end{array}$ & $\begin{array}{c}1 \\
5.3 \%\end{array}$ & $\begin{array}{c}14 \\
6.7 \%\end{array}$ & $\begin{array}{c}28 \\
7.5 \%\end{array}$ & $\begin{array}{c}1 \\
4.2 \%\end{array}$ & $\begin{array}{c}48 \\
6.9 \%\end{array}$ & $\begin{array}{c}\chi^{2}=0.079 \\
p=0.93966\end{array}$ \\
\hline
\end{tabular}

* Values do not add up to 100 due to the possibility of multiple choice

Table 2. Respondents' opinion on the relationship between shift work and ischemic heart disease and hypertension

\begin{tabular}{|c|c|c|c|c|c|}
\hline \multirow{2}{*}{\multicolumn{2}{|c|}{$*$}} & \multicolumn{4}{|c|}{$\begin{array}{l}\text { Shift work as a reason for the deterioration of respondents' } \\
\text { health }\end{array}$} \\
\hline & & Yes & No & Summary & Statistic \\
\hline \multirow{2}{*}{$\begin{array}{l}\text { Shift work as the cause of } \\
\text { exacerbation of: }\end{array}$} & IHD & $\begin{array}{c}15 \\
3.5 \%\end{array}$ & $\begin{array}{c}2 \\
0.7 \%\end{array}$ & $\begin{array}{c}17 \\
2.4 \%\end{array}$ & $\begin{array}{c}\chi^{2}=5.09 \\
p=0.02407\end{array}$ \\
\hline & Hypertension & $\begin{array}{c}42 \\
9.7 \% \\
\end{array}$ & $\begin{array}{c}6 \\
2.3 \% \\
\end{array}$ & $\begin{array}{c}48 \\
6.9 \% \\
\end{array}$ & $\begin{array}{c}\chi^{2}=14.22 \\
p=0.00016\end{array}$ \\
\hline
\end{tabular}

* Values do not add up to 100 due to the possibility of multiple choice

Table 3. The duration of hypertension and pressure values of $>139 / 89 \mathrm{mmHg}$ by age of respondents

\begin{tabular}{|c|c|c|c|c|c|c|c|}
\hline & & & & ge [year & & & \\
\hline \multirow{3}{*}{$\begin{array}{c}\text { Duration of } \\
\text { hypertension }\end{array}$} & & $21-30$ & $31-40$ & $41-50$ & $\begin{array}{l}51 \text { and } \\
\text { more }\end{array}$ & Summary & Statistic \\
\hline & $1-5$ & $\begin{array}{c}2 \\
100.0 \%\end{array}$ & $\begin{array}{c}7 \\
70.0 \% \\
\end{array}$ & $\begin{array}{c}22 \\
51.2 \%\end{array}$ & $\begin{array}{c}3 \\
50.0 \% \\
\end{array}$ & $\begin{array}{c}34 \\
55.7 \% \\
\end{array}$ & \multirow{2}{*}{$\begin{array}{c}\chi^{2}=2.86 \\
p=0.41411\end{array}$} \\
\hline & 6 and more & $\begin{array}{c}0 \\
0.0 \% \\
\end{array}$ & $\begin{array}{c}3 \\
30.0 \% \\
\end{array}$ & $\begin{array}{c}21 \\
48.8 \% \\
\end{array}$ & $\begin{array}{c}3 \\
50.0 \% \\
\end{array}$ & $\begin{array}{c}27 \\
44.3 \% \\
\end{array}$ & \\
\hline \multirow{2}{*}{$\begin{array}{l}\text { Blood pressure values } \\
\text { of }>139 / 89 \mathrm{mmHg}\end{array}$} & Yes & $\begin{array}{c}13 \\
11.6 \% \\
\end{array}$ & $\begin{array}{c}39 \\
18.8 \% \\
\end{array}$ & $\begin{array}{c}111 \\
31.9 \% \\
\end{array}$ & $\begin{array}{c}7 \\
21.2 \% \\
\end{array}$ & $\begin{array}{c}170 \\
24.3 \% \\
\end{array}$ & \multirow{2}{*}{$\begin{array}{c}\chi^{2}=24.26 \\
p=0.00002\end{array}$} \\
\hline & No & $\begin{array}{c}99 \\
88.4 \% \\
\end{array}$ & $\begin{array}{c}168 \\
81.2 \% \\
\end{array}$ & $\begin{array}{c}237 \\
68.1 \% \\
\end{array}$ & $\begin{array}{c}26 \\
78.8 \% \\
\end{array}$ & $\begin{array}{c}530 \\
75.7 \% \\
\end{array}$ & \\
\hline
\end{tabular}

Table 4. Blood pressure values $>139 / 89 \mathrm{mmHg}$ and treatment for hypertension with reference the number of years of shift work

\begin{tabular}{|c|c|c|c|c|c|c|}
\hline & & \multicolumn{5}{|c|}{ Number of years worked in the shift type } \\
\hline & & 1-10 & 11-20 & $\begin{array}{l}21 \text { and } \\
\text { more }\end{array}$ & Summary & Statistic \\
\hline \multirow{2}{*}{$\begin{array}{c}\text { Blood pressure values of } \\
>139 / 89 \mathrm{mmHg}\end{array}$} & Yes & $\begin{array}{c}30 \\
14.5 \%\end{array}$ & $\begin{array}{c}81 \\
27.2 \%\end{array}$ & $\begin{array}{c}59 \\
30.3 \%\end{array}$ & $\begin{array}{c}170 \\
24.3 \%\end{array}$ & \multirow{2}{*}{$\begin{array}{c}\chi^{2}=15.94 \\
p=0.00035\end{array}$} \\
\hline & No & $\begin{array}{c}177 \\
85.5 \%\end{array}$ & $\begin{array}{c}217 \\
72.8 \%\end{array}$ & $\begin{array}{c}136 \\
69.7 \%\end{array}$ & $\begin{array}{c}530 \\
75.7 \%\end{array}$ & \\
\hline \multirow{2}{*}{ Treatment for hypertension } & Yes & $\begin{array}{c}6 \\
2.9 \% \\
\end{array}$ & $\begin{array}{c}28 \\
9.4 \% \\
\end{array}$ & $\begin{array}{c}27 \\
13.8 \% \\
\end{array}$ & $\begin{array}{c}61 \\
8.7 \% \\
\end{array}$ & \multirow{2}{*}{$\begin{array}{c}\chi^{2}=15.43 \\
p=0.00045\end{array}$} \\
\hline & No & $\begin{array}{c}201 \\
97.1 \%\end{array}$ & $\begin{array}{c}270 \\
90.6 \%\end{array}$ & $\begin{array}{c}168 \\
86.2 \%\end{array}$ & $\begin{array}{c}639 \\
91.3 \%\end{array}$ & \\
\hline
\end{tabular}


Table 5. Dyslipidemia according to age

\begin{tabular}{|c|c|c|c|c|c|c|c|}
\hline & & \multicolumn{5}{|c|}{ Age [years] } & \multirow[b]{2}{*}{ Statistic } \\
\hline$*$ & & $21-30$ & $31-40$ & $41-50$ & $\begin{array}{c}51 \text { and } \\
\text { more }\end{array}$ & Summary & \\
\hline \multirow{4}{*}{$\begin{array}{c}\text { Dyslipidemic } \\
\text { parameters }\end{array}$} & $\begin{array}{c}\text { Total } \\
\text { cholesterol }\end{array}$ & $\begin{array}{c}0 \\
0.0 \%\end{array}$ & $\begin{array}{c}10 \\
4.8 \%\end{array}$ & $\begin{array}{c}36 \\
10.3 \%\end{array}$ & $\begin{array}{c}5 \\
15.1 \%\end{array}$ & $\begin{array}{c}51 \\
7.3 \%\end{array}$ & $\begin{array}{c}\chi^{2}=18.49 \\
p=0.00035\end{array}$ \\
\hline & $\begin{array}{c}\text { Cholesterol } \\
\text { LDL }\end{array}$ & $\begin{array}{c}0 \\
0.0 \% \\
\end{array}$ & $\begin{array}{c}2 \\
1.0 \% \\
\end{array}$ & $\begin{array}{c}9 \\
2.6 \% \\
\end{array}$ & $\begin{array}{c}0 \\
0.0 \% \\
\end{array}$ & $\begin{array}{c}3 \\
9.1 \% \\
\end{array}$ & $\begin{array}{c}\chi^{2}=12.49 \\
\mathrm{p}=0.00588\end{array}$ \\
\hline & $\begin{array}{c}\text { Cholesterol } \\
\text { HDL }\end{array}$ & $\begin{array}{c}0 \\
0.0 \%\end{array}$ & $\begin{array}{c}1 \\
0.5 \%\end{array}$ & $\begin{array}{c}17 \\
4.9 \%\end{array}$ & $\begin{array}{c}2 \\
6.1 \%\end{array}$ & $\begin{array}{c}20 \\
2.9 \%\end{array}$ & $\begin{array}{c}\chi^{2}=13.87 \\
p=0.00308\end{array}$ \\
\hline & Triglycerides & $\begin{array}{c}1 \\
0.9 \%\end{array}$ & $\begin{array}{c}4 \\
1.9 \% \\
\end{array}$ & $\begin{array}{c}10 \\
2.9 \% \\
\end{array}$ & $\begin{array}{c}3 \\
9.1 \% \\
\end{array}$ & $\begin{array}{c}18 \\
2.6 \% \\
\end{array}$ & $\begin{array}{c}\chi^{2}=7.32 \\
p=0.06231\end{array}$ \\
\hline
\end{tabular}

* values do not add up to 100 due to the possibility of multiple choice

Table 6. Dyslipidemic parameters according to number of years of shift work

\begin{tabular}{|c|c|c|c|c|c|c|}
\hline & & \multicolumn{5}{|c|}{ Number of years worked in the shift type } \\
\hline & & $\mathbf{1 - 1 0}$ & $\mathbf{1 1 - 2 0}$ & $\mathbf{2 1 a n d}$ more & Summary & Statistic \\
\hline \multirow{4}{*}{ Dyslipidemic parameters } & Total & 2 & 29 & 20 & 51 & $\chi^{2}=17.42$ \\
& cholesterol & $1.0 \%$ & $9.7 \%$ & $10.3 \%$ & $7.3 \%$ & $\mathrm{p}=0.00016$ \\
\cline { 2 - 8 } & Cholesterol & 0 & 9 & 5 & 14 & $\chi^{2}=6.12$ \\
& LDL & $0.0 \%$ & $3.0 \%$ & $2.6 \%$ & $2.0 \%$ & $\mathrm{p}=0.04681$ \\
\cline { 2 - 8 } & Cholesterol & 1 & 10 & 9 & 20 & $\chi^{2}=6.64$ \\
& HDL & $0.5 \%$ & $3.4 \%$ & $4.6 \%$ & $2.9 \%$ & $\mathrm{p}=0.03612$ \\
\cline { 2 - 8 } & \multirow{2}{*}{ TGL } & 3 & 10 & 5 & 18 & $\chi^{2}=1.77$ \\
$\mathrm{n}=0.41228$ \\
\hline
\end{tabular}

* values do not add up to 100 due to the possibility of multiple choice

Table 7. Dyslipidemic parameters according to work position

\begin{tabular}{|c|c|c|c|c|c|c|}
\hline \multirow[b]{2}{*}{$*$} & & \multicolumn{5}{|c|}{ Work position } \\
\hline & & Supervisor & Miner & Over & Summary & Statistic \\
\hline \multirow{4}{*}{ Dyslipidemic parameters } & $\begin{array}{c}\text { Total } \\
\text { cholesterol }\end{array}$ & $\begin{array}{c}5 \\
11.6 \% \\
\end{array}$ & $\begin{array}{c}39 \\
7.5 \% \\
\end{array}$ & $\begin{array}{c}7 \\
5.0 \% \\
\end{array}$ & $\begin{array}{c}51 \\
7.3 \% \\
\end{array}$ & $\begin{array}{c}\chi^{2}=2.29 \\
p=0.31869\end{array}$ \\
\hline & $\begin{array}{c}\text { Cholesterol } \\
\text { LDL }\end{array}$ & $\begin{array}{c}0 \\
0.0 \%\end{array}$ & $\begin{array}{c}10 \\
1.9 \%\end{array}$ & $\begin{array}{c}4 \\
2.9 \%\end{array}$ & $\begin{array}{c}14 \\
2.0 \%\end{array}$ & $\begin{array}{c}\chi^{2}=1.44 \\
p=0.48757\end{array}$ \\
\hline & $\begin{array}{c}\text { Cholesterol } \\
\text { HDL }\end{array}$ & $\begin{array}{c}1 \\
2.3 \% \\
\end{array}$ & $\begin{array}{c}16 \\
3.1 \% \\
\end{array}$ & $\begin{array}{c}3 \\
2.2 \% \\
\end{array}$ & $\begin{array}{c}20 \\
2.9 \% \\
\end{array}$ & $\begin{array}{c}\chi^{2}=0.39 \\
p=0.82344\end{array}$ \\
\hline & TGL & $\begin{array}{c}4 \\
9.3 \%\end{array}$ & $\begin{array}{c}10 \\
1.9 \%\end{array}$ & $\begin{array}{c}4 \\
2.9 \% \\
\end{array}$ & $\begin{array}{c}18 \\
2.6 \%\end{array}$ & $\begin{array}{c}\chi^{2}=8.68 \\
p=0.01306\end{array}$ \\
\hline
\end{tabular}

* values do not add up to 100 due to the possibility of multiple choice

Table 8. Shift work as a cause of deterioration of respondents' health according to dyslipidemia

\begin{tabular}{|c|c|c|c|c|c|}
\hline \multirow{2}{*}{$*$} & & \multicolumn{3}{|c|}{ Shift work as a reason for the deterioration of } \\
respondents' health
\end{tabular}

* values do not add up to 100 due to the possibility of multiple choice 


\section{Discussion}

Epidemiologic studies show an increased prevalence of cardiovascular disease in night workers versus day workers, and field studies in shift workers have shown increased inflammatory markers and blood pressure during or following night work compared to day work or days off [5]. A prospective cohort study examined the relationship between rotating night shift work and coronary artery disease over 24 years of follow-up and found that $\geq 5$ years of rotating night shift was associated with a significantly increased risk of coronary heart disease [11]. In our study, people who believed that shift work can lead to deterioration of health also believed that shift work may affect the occurrence of IHD (3.5\%) and hypertension (9.7\%).The study of Asare-Anane showed that hypertension was more prevalent among shift workers aged between 30 and 49 years of age. This study also showed a decreasing trend in the prevalence of hypertension among the shift workers aged 50-59. This observation could be due to more stressful jobs being given to the younger workers and leaving the less stressful jobs for the older workers. Continued shift work could also lead to adaptation of biological rhy thms that do not promote hypertension [2]. It has been reported that shift work is associated with an increased prevalence of hypertension, but data are inconclusive [12]. In our study, blood pressure was higher than $139 / 89 \mathrm{mmHg}$ in one in four workers, with hypertension significantly more frequent among men aged 41-50 (31.9\%). In the other studies, elevated cholesterol levels among shift workers were observed and an elevated triglyceride level was reported to be associated with shift work $[2,13]$. This may be due to reduced sleep duration associated with the shift work. Reduced sleep has been linked to disruption of biological rhythms and dyslipidemia [2, 14]. Different studies have confirmed a direct relationship between shift work and cardiac disease and dyslipidemia. However, data are conflicting, with Akbari et al. reporting no relationship between shift work and changes in serum triglyceride and cholesterol [15]. In our study, a small percent of respondents reported abnormal values of HDL cholesterol (3.9\%), triglycerides (3.9\%) and total cholesterol (8.74\%), p $\leq 0.05$.

\section{Conclusions}

1. In the opinion of respondents in this study, shift work can exacerbate hypertension and ischemic heart disease. One in four respondents reported blood pressure $>139 / 89 \mathrm{mmHg}$ during regular measurements, out of whom one in ten was being treated for hypertension.

2. Abnormal total cholesterol and LDL and HDL cholesterol fractions increased with age and length of work, while abnormal triglyceride values were reported most frequently by supervisors.

3. It seems necessary to introduce training for shift workers, aimed at presenting them with the principles of prevention of cardiovascular diseases; for example, how to deal with stress, change eating habits, stop smoking and reduce coffee intake, and how to encourage physical activity and good sleep hygiene.

\section{References:}

1. Parliamentary Office of Science and Technology. The 24-hour society. Postnote [Internet]. 2005 [cited 2019 Feb 28]; 250(11): [about 4 p.]. Available from: http://www.parliament.uk/parliamentary_offices/post/ pubs2005.cfm.

2. Asare-Anane H, Abdul-Latif A, Kwaku Ofori E, Abdul-Rahman M, Amanquah SD. Shift work and the risk of cardiovascular disease among workers in cocoa processing company, Tema. BMC Res Notes. 2015; 8: 798. https://doi.org/10.1186/s13104-015-1750-3

3. Tenkanen L, Sjöblom T, Kalimo R, Alikoski T, Härmä M. Shift work, occupation and coronary heart disease over 6 years of follow-up in the Helsinki Heart Study. Scand J Work Environ Health. 1997; 23(4): $257-65$. https://doi.org/10.5271/sjweh.218

4. Bonham MP, Leung GKW, Davis R, Sletten TL, Murgia C, Young MJ, et al. Does modifying the timing of meal intake improve cardiovascular risk factors? Protocol of an Australian pilot intervention in night shift workers with abdominal obesity. BMJ Open. 2018; 8: e020396. https://doi.org/10.1136/bmjopen-2017-020396

5. Morris CJ, Purvis TE, Mistretta J, Hu K, Scheer FA. Circadian misalignment increases C-reactive protein and blood pressure in chronic shift workers. J Biol Rhythms. 2017; 32(2): 154-164. https://doi.org/10.1177/0748730417697537

6. Canadian Centre for Occupational Health and Safety (CCOHS) [Internet]. Hamilton: Canadian Centre for Occupational Health and Safety; 1999. Rotational shiftwork [cited 2010 November 9]. Available from: http://www.ccohs.ca/oshanswers/work_schedules/shiwtwrk.html

7. Strzemecka J, Bojar I, Strzemecka E, Owoc A. Dietary habits among persons hired on shift work. Ann Agric Environ Med. 2014; 21(1): 128-131. 
8. Skogstad M, Mamen A, Lunde LK, Ulvestad B, Matre D, Aass HC, et al. Shift work including night work and long working hours in industrial plants increases the risk of atherosclerosis. Int J Environ Res Public Health. 2019; 16(3): 521. https://doi.org/10.3390/ijerph16030521

9. Hulsegge G, Gupta N, Proper KI, van Lobenstein N, IJzelenberg W, Hallman DM, et al. Shift work is associated with reduced heart rate variability among men but not women. Int J Cardiol. 2018; 258: $109-114$. https://doi.org/10.1016/j.ijcard.2018.01.089

10. Elliott JL, Lal S. Blood pressure, sleep quality and fatigue in shift working police officers: effects of a twelve hour roster system on cardiovascular and sleep health. Int. J. Environ. Res. Public Health. 2016, 13(2): 172. https://doi.org/10.3390/ijerph13020172

11. Vetter C, Devore EE, Wegrzyn LR, Massa J, Speizer FE, Kawachi I, et al. Association between rotating night shift work and risk of coronary heart disease among women. JAMA. 2016; 315(16): 1726-1734. https://doi.org/10.1001/jama.2016.4454

12. Lu K, Chen J, Wang L, Wang C, Ding R, Wu S, et al. Association of sleep duration, sleep quality and shiftwork schedule in relation to hypertension prevalence in Chinese adult males: a cross-sectional survey. Int. J. Environ. Res. Public Health. 2017; 14(2): 210. https://doi.org/10.3390/ijerph14020210

13. Ha M, Park J. Shift work and metabolic risk factors of cardiovascular disease. J Occup Health. 2005; 47(2): 89-95.

14. Broussard J, Brady MJ. The impact of sleep disturbances on adipocyte function and lipid metabolism. Best Pract Res Clin Endocrinol Metab. 2010; 24(5): 763-73. https://doi.org/10.1016/j.beem.2010.08.007

15. Akbari H, Mirzaei R, Nasrabadi T, Gholami-Fesharaki M. Evaluation of the effect of shift work on serum cholesterol and triglyceride levels. Iran Red Crescent Med J. 2015; 17(1): e18723.

https://doi.org/10.5812/ircmj.18723 